leaves only a good teacher to be desired, and itself helps to form and train him. The confirming of this Regulation will be a great step towards that much-to-be-desired state of things when a laboratory will be considered as necessary a part of a school as a class-room, bottles and bones as essential as books and boards. But we must not ignore what has already been done in schools like Eton and Rugby; with their laboratories and museums, such a Regulation is superfluous; but with the good work which has been accomplished before us, we have a happy omen of the result of the universal application of the principle they have voluntarily aclopted. It is from these schools and others not included in the "nine," that have not fitted up their laboratories, that the Natural Science scholars are obtained, and perhaps the proportion of such scholarships to all others is as great as that of schools with laboratories to those without-probably greater. As the number of science-teaching schools increases the number of scholarships must increase too, but not at the same rate ; the proper and final proportion may be left to settle itself.
On the whole we may regard these proposed Regulations with the greatest satisfaction, and it is probable that they will be looked back upon as the charter of the country's progress in scientific education. Individual efforts have been made on a grand scale, and natural science is making its way more or less efficiently into all good schools, while some are devoting themselves chiefly to its cultivation, as Taunton, Giggleswick, Burnley ; but universal recognition, its acquirement of prestige, and consequent respect and earnest study, with the national advantages to be derived from it, can only be secured by such Regulations as these, followed or not as may be neces. sary, by similar ones for all the larger endowed schools.

\section{THE SUB-WEALDEN EXPLORATION}

$\mathrm{T}$ the word romance were to be imported into scientific 1 literature there could surely be no more fitting application of it than to this recent crusade into the bowels of the earth among the woods and lanes of Sussex. Down in that southern part of the country, some hundreds of

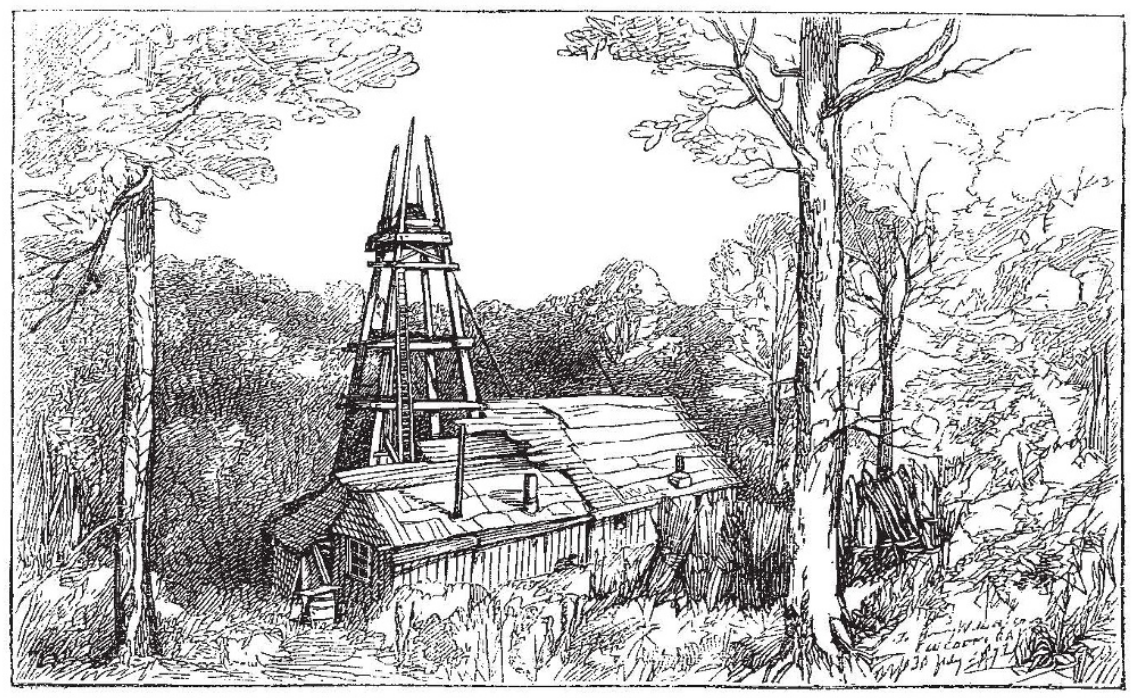

The Sub-Wealden Exploration in Sussex-Boring at Netherfield. (Kindly lent by the Proprietors of the Graphic.)

miles áway frem the great centres of our mineral industry, with no prospect of any pecuniary reward or of any immcdiate economic advantage, men are found willing to subscribe money to the extent of thousands of pounds for the purpose of settling definitely some important questions in the geology of the south-east of England, viz. at what depth from the surface the secondary strata are underlain by a ridge or platform of old Palæozoic rocks, what are the nature and age of these bottom rocks of the district, and what is the arrangement of the strata lying between them and the surface. It has long been a problem of much interest to geologists to discover whether or in what manner the great series of Jurassic rocks, which stretches across our island from the coasts of Dorsetshire to those of Yorkshire, passes south-eastward underneath the chalk. That series has been found to grow thinner towards the south-east. On the French side of the Channel it reappears in the Boulonnais, coming out from under the Cretaeeous strata and resting against a ridge of
Palæozoic rocks which rise to the surface between Boulogne and Calais. Nearly twenty years ago $\mathrm{Mr}_{\mathrm{r}}$. Godwin Austen drew attention to the probable extension of this ridge underneath the later formations of the south-east of England and its connection with the Carboniferous tracts in our south-western counties. It was a point of great interest in any attempt to reconstruct a map of the physical geography of western Europe during Palaozoic times. Hence, at intervals since the publication of $\mathrm{Mr}$. Austen's great memoir, renewed attention has been given to the subject, until at last the idea took shape that a bold attempt should be made to settle some portion at least of the problem by putting down a bore and keeping it going, if possible, until all the Secondary rocks should be pierced and definite information should be obtained as to what lies below them. Advantage was taken of the meeting of the British Association at Brighton in 1872 to organise the scheme. For so purely scientific a project it was of course natural to look for help mainly to such well-wishers 
to science as attend the Association meetings, rather than to the general public. Subscription lists were opened and money, came in, not in overflowing abundance indeed, but yet in quantity sufficient to enable the operations to be begun. Further donations have been given, and the work has now been carried down to a depth of more than $\mathrm{I}, 000 \mathrm{ft}$.

It would be a great misfortune to science if this undertaking, after having been successfully carried so far, were now to be brought to an abrupt close for want of funds. Already the boring has put us in possession of some new and important facts in the geology of the south-east of England. It has shown that the well-known Kimmeridge clay stretches underneath the later Secondary rocks as a deep massive formation, some $700 \mathrm{ft}$. in thickness, and that it lies upon and appears to pass down into the Oxford clay without the intervention of the sandy and calcareous beds which usually separate the two deposits. The geological position of these clays is settled by means of the fossils, of which literally thousands have been taken out of the 2 -in. core of rock brought up by the diamondboring machine. It is intended, we believe, to sort the specimens and distribute them among different public museums. How much further the bore must be sunk before the remainder of the Secondary strata is pierced, to what horizons these strata will be assignable, and what will be their basement rocks, are the parts of the problem still to be solved.

Though undertaken chiefly in the interest of pure science, the project has likewise its economic aspects. It is eminently desirable to know whether any minerals of value lie among the Secondary rocks of the south of England, such as iron-stone, rock-salt, or gypsum; whether among the Palazozoic rocks underneath there is any possibility of obtaining workable coal or any of the other minerals which have made the Carboniferous formations so valuable a source of our wealth. It is likewise greatly to be wished that as full and accurate information as possible should be obtained regarding the nature of the rocks underneath with reference to the question of water-supply-a question which, important enough now, is certain before many years to become one of the most pressing social problems of the day.

On every ground, therefore, this most heroic attempt to provide data for settling some of these questions dcserves hearty encouragement. On no account must it be allowed to come to an end till its express object is accomplished. If every well-wisher to science in this country would but send his contribution, not only would the present boring be conducted to a successful issue, but a great series of similar borings might be made all over the south of England. We understand that the Government, impressed with the interest and importance of the subject, has promised to contribute a sum of $\mathrm{r}, \mathrm{0o0} l$. conditionally upon coal being found or on the boring being continued for another $\mathrm{r}, \mathrm{ooo} \mathrm{ft}$. This aid will be valuable, but it evidently in the meantime does not supersede private efforts; it rather makes them more needful than ever. The undertaking is in excellent hands. Mr. Topley, of the Geological Survey, looks after its geological aspects. To Mr. Henry Willett, of Arnold House, Brighton, the zealous and indefatigable honorary secretary, the enterprise is mainly indebted for its financial progress so far. $\mathrm{He}$ has now appealed earnestly for further help, and to him we would urge all who take interest in these matters, and who have not already contributed, to send their donations, which, whether small or large, will at the present moment be of the most essential service.

A. G.

\section{THE SCIENCE OF PAINTING}

Die Farbenlehre im Finblick auf Kunst und Kunstgewerbe. Von Prof. Wilhelm von Bezold.

7 HERE are two ways of popularising science. We may take up one of its great branches and treat it so simply and clearly that even the unscientific reader may with proper attention gain some insight into the principles to which the recent great advances in science have been chiefly due; or we may take up a smaller field and treat it fully and with all its applications in everyday life. He who studies a subject by the latter method will have it constantly brought under his notice, and will thus be led to observe and perhaps to experiment, and to acquire for himself that method of looking at the phenomena of nature and reasoning about them which is necessary to the understanding of every great principle in science, but which is foreign to nearly all who have not had a scientific training.

The latter method, which no doubt will prove the most successful, has been chosen by Prof. von Bezold in his work on the theory of colours. No subject is better fitted to be treated in this way, because it is in everybody's power to make observations, and perhaps even to find out some new fact. It is, however, not the only, and not even the chief, object of the author to create merely an interest in his subject outside the scientific world. $\mathrm{He}$ wishes his book to be of real value to the artist and to help him by theoretical speculations to such combinations of colour as shall prove most effectual. It is very doubtful whether the book will be successful in this respect. No doubt it would be a great achievement if every artist could be induced to think about the cause of the various and curious effects which are brought about by contrast and combination of colours; we therefore recommend the careful perusal of Prof. von Bezold's book to every painter. In the present state of the thecry of colours, however, the attention bestowed upon it by artists will be of greater value to the subject than to themselves. It would no doubt be injurious to art if the painter were guided in his work by a theory so long as that theory is incomplete.

Painters are, however, themselves best able to bring the theory of colours into a better state; a state in which it will be beneficial to themselves and repay them for their trouble.

Two things have chiefly struck us in Prof. von Bezold's book as adding to its value and interest. The first is the care which he has taken to give his experiments in such a way that anyone without the use of large and expensive apparatus can repeat them and test for himself the truth of the author's statements. The second is the great ingenuity with which the author explains by his theory so many of the phenomena which most of us daily observe. We note one particular instance. All who have worked much at absorption spectra must have been struck by the 